\title{
EAERE Award for the Best Paper Published in Environmental and Resource Economics During 2019
}

\author{
Phoebe Koundouri ${ }^{1}$ - Astrid Dannenberg ${ }^{2} \cdot \operatorname{lan}$ J. Bateman ${ }^{3}$
}

Accepted: 24 March 2020 / Published online: 2 April 2020

(c) Springer Nature B.V. 2020

\begin{abstract}
We present details of the EAERE Award for the Best Paper Published in Environmental and Resource Economics During 2019 together with those Highly Commended papers published during this period.
\end{abstract}

Keywords EAERE award - Best paper - Published in environmental and resource economics $\cdot 2019$

For nearly a decade the European Association of Environmental and Resource Economists (EAERE) has awarded a prize at its annual conference, generously donated by Springer, for the best paper published within its journal Environmental and Resource Economics (ERE). At the time of writing the global coronavirus pandemic has resulted in a suspension of the annual conference. Nevertheless, the Association is keen to acknowledge leading work in the field of environmental and resource economics and continue this award.

To advise upon this award, the Association called together a panel Chaired by EAERE President Phoebe Koundouri, assisted by two other members of the ERE Editorial Board, Astrid Dannenberg and Ian Bateman. Together this panel evaluates all papers published by the journal over the previous calendar year. Following this advice, we are pleased to announce that the EAERE Award for the Best Paper Published in Environmental and Resource Economics During 2019 goes to:

Phoebe Koundouri

pkoundouri@aueb.gr

Astrid Dannenberg

dannenberg@uni-kassel.de

Ian J. Bateman

I.Bateman@exeter.ac.uk

1 School of Economics, Athens University of Economics and Business, Athens, Greece

2 Environmental and Behavioral Economics, University of Kassel, Kassel, Germany

3 Land, Environment, Economics and Policy Institute (LEEP), Environmental Economics, University of Exeter Business School, Exeter, UK 
Luis Moisés Peña-Lévano, Farzad Taheripour and Wallace E. Tyner for their superb paper "Climate Change Interactions with Agriculture, Forestry Sequestration, and Food Security".

In this superb paper the authors produce both a truly excellent example of multidisciplinary collaboration and internationally significant contribution to our understanding of the interplay between climate change, mitigation policies, and their impacts on the global economy. Their paper addresses a context in which climate change threatens to negatively affect crop productivity in many regions across the world. Add to this inelastic demand for most agricultural products then a climate or otherwise driven shock in food supply can result in food price increases, limiting the ability of some regions to provide adequate food supplies for population needs. Such circumstances undermine calls for reductions of deforestation and reforestation despite these being recognized as efficient and effective approaches for mitigating climate change.

Given such a context Peña-Lévano, Taheripour and Tyner address a series of fundamental questions: (1) What is the cost of emissions reduction with no forest carbon sequestration (FCS) incentive? (2) What is the mitigation cost incorporating FCS? (3) What are the impacts of FCS on food security? (4) What are the consequences for the global economy and food production when crop productivity is affected by climate change? (5) What is the economic value of reducing crop yield losses?

The authors modify a well-known computable general equilibrium (CGE) model (GTAP-BIO-FCS) to evaluate the economic and land use impacts of emissions reduction targets and policies under alternative climate scenarios. They find that implementing an aggressive FCS incentive can cause substantial increases in food prices due to land competition between forest and crop production. In fact, when climate-induced yield shocks are integrated in the analysis, food price increases are so large that it becomes clear that such an approach could not be adopted in the real world. Moreover, the results cry out for investment in agricultural research on climate adaptation, as the authors find that economic well-being falls more without mitigation, than with $50 \%$ emission reductions.

This paper is an excellent example of how economics can deliver the much-needed Sustainability Transition, by providing useful guidance for policy-making which derives from careful multidisciplinary modeling and economic analysis. EAERE is grateful to the authors for their devotion to producing pioneering policy-relevant work. We note with regret that Prof. Wallace E. Tyner passed away last Summer.

In addition to various cash and book voucher prizes, the publishers, Springer, are making the paper freely available for download for an 8-week period following publication.

The panel felt that this was a good year for high quality submissions and the following papers were awarded "Highly Commended" status:

Partha Dasgupta, Tapan Mitra and Gerhard Sorger, "Harvesting the Commons".

Takahiko Kiso, "Environmental Policy and Induced Technological Change: Evidence from Automobile Fuel Economy Regulations".

Thomas Eichner and Rüdiger Pethig, "Coaseian Biodiversity Conservation and Market Power".

Each of these papers was identified as representing very substantial contributions to the field of environmental and resource economics and the authors are congratulated for such fine work. Full references to all papers are provided below. 


\section{References}

Dasgupta P, Mitra T, Sorger G (2019) Harvesting the Commons. Environ Resource Econ 72:613-636. https ://doi.org/10.1007/s10640-018-0221-4

Eichner T, Pethig R (2019) Coaseian biodiversity conservation and market power. Environ Resource Econ 72:849-873. https://doi.org/10.1007/s10640-018-0225-0

Kiso T (2019) Environmental policy and induced technological change: evidence from automobile fuel economy regulations. Environ Resource Econ 74:785-810. https://doi.org/10.1007/s10640-019-00347 $-6$

Peña-Lévano LM, Taheripour F, Tyner WE (2019) Climate change interactions with agriculture, forestry sequestration, and food security. Environ Resour Econ 74:653-675. https://doi.org/10.1007/s1064 0-019-00339-6 (with correction available at https://doi.org/10.1007/s10640-019-00343-w)

Publisher's Note Springer Nature remains neutral with regard to jurisdictional claims in published maps and institutional affiliations. 